\title{
The first species of Trichopsomyia Williston, 1888 (Diptera: Syrphidae) described from the Oriental region, with a discussion on the character states of the pilosity of the katepisternum
}

\author{
Jeroen van STEENIS ${ }^{1, *} \&$ Nigel P. WYATT ${ }^{2}$ \\ ${ }^{1}$ Research Associate Naturalis Biodiversity Center, Leiden; c/o Hof der Toekomst 48, \\ 3823 HX Amersfoort, the Netherlands. \\ ${ }^{2}$ Department of Life Science, The Natural History Museum, Cromwell Road, \\ London SW7 5BD, United Kingdom. \\ *Corresponding author: jvansteenis@syrphidaeintrees.com \\ ${ }^{2}$ Email: N.Wyatt@nhm.ac.uk \\ ${ }^{1}$ urn:lsid:zoobank.org:author:C7F0D01C-B182-4B93-AF73-E4154367B535 \\ ${ }^{2}$ urn:1sid:zoobank.org:author:46C91F9E-11F3-4286-8958-2A83DE40CC8F
}

\begin{abstract}
The first Oriental species of the genus Trichopsomyia Williston, 1888, Trichopsomyia pilosa sp. nov. (Java), has been discovered and is now described. This Oriental species of Trichopsomyia has several characters strongly differing from the other species within this genus. It is hypothesized that it forms a separate group within Trichopsomyia. One species, Trichopsomyia formiciphila Downes, Skevington \& Thompson, 2017, from Australia, is similar to the Oriental species described here, and the group is named after this first described species, hence the formiciphila group. The characters for a future phylogenetic analysis are discussed. The character states of the pilosity of the katepisternum and the shape of the metasternum hitherto used in a phylogenetic analysis of Syrphidae Latreille, 1802 are discussed too.
\end{abstract}

Keywords. Trichopsomyia formiciphila group, new species, Oriental region, character states of the metasternum and katepisternum.

Steenis J. van \& Wyatt N.P. 2020. The first species of Trichopsomyia Williston, 1888 (Diptera: Syrphidae) described from the Oriental region, with a discussion on the character states of the pilosity of the katepisternum. European Journal of Taxonomy 687: 1-12. https://doi.org/10.5852/ejt.2020.687

\section{Introduction}

Syrphidae Latreille, 1802 is a worldwide occurring dipterous family with several sub-families and species having very a different larval habitat and adult behaviour (Rotheray \& Gilbert 2011). Many species are regarded as key pollinators of wild plants and crops, some are used for the natural control of aphids or as pulp decomposers while others are regarded as pests to bulbous plants (Bergh \& Short 2008; Bugg et al. 2008; Ssymank \& Kearns 2009; Morales \& Wolff 2010). Within one genus, most species 
show the same way of life, and this could help in finding larvae or adults and get to know more about their natural history (Rotheray \& Gilbert 1999; Rojo et al. 2003).

The Oriental Syrphidae fauna is one of the least studied (e.g., Thompson \& Skevington 2014), requiring more efforts as this part of the world is under great threat due to human influences and part of its syrphid fauna could already be lost (e.g., Hippa et al. 2015). The discovery of a new species of the genus Trichopsomyia Williston, 1888 for the Oriental region was the starting point of this research and this paper, with the hope to stimulate further research.

The genera, of which Trichopsomyia is one, grouped together with Pipiza Fallén, 1810, often classified as the tribe Pipizini Williston, 1885, are welldefined with some unique morphological characters (Thompson 1972; Kuznetsov 1988, 1992; Rotheray \& Gilbert 1989; Hippa \& Ståhls 2005; Vujić et al. 2013; Mengual et al. 2015). The adults of species of pipizine are small to medium-sized hoverflies $(5-10 \mathrm{~mm})$ with a mainly black-coloured body, a flat face which is not produced forwards and a round oral cavity (Vujić et al. 2013).

Larvae of pipizine are predatory and show a preference for woolly or root aphids with waxy secretions or gall-forming hemipterans, for example, Aphididae Latreille, 1802, Psyllidae Latreille, 1807, Phylloxeridae Herrich-Schaeffer, 1854 and Adelgidae Schouteden, 1909 (Rojo et al. 2003; Steenis et al. 2018). One Australian species is associated with weaver ants (Downes et al. 2017). The eggs of pipizines have a ribbed surface and the posterior respiratory process consisting of separate tubes on two strongly sclerotized processes in the first instar larva, both characters unique among Syrphidae (Kuznetsov 1988, 1992).

The classification of the pipizines has been a longstanding taxonomic problem as they have been grouped within Syrphinae Latreille, 1802, Eristalinae Newman, 1834 or even treated as a separate subfamily. The larval feeding mode is shared with the Syrphinae, but several adult characters are shared with the Eristalinae (e.g., Thompson 1972; Cheng et al. 2000) including a pilose postpronotum (bare in Syrphinae) and male abdomen with four unmodified pregenital segments (five in Syrphinae). As earlier proposed by Williston (1885) and Kuznetsov (1992), the recent combined morphological and molecular cladistic analyses showed that this group of genera deserves the rank of sub-family, the Pipizinae Williston, 1885 (Mengual et al. 2015).

Pipizinae has an almost worldwide distribution, but it is not known from the Afrotropical region, with most of its genera and species occurring in the Palaearctic region (Mutin 1998; Steenis \& Lucas 2011; Huang \& Cheng 2012; Vujić et al. 2013; Pape \& Evenhuis 2018). Knutson et al. (1975) listed three species from two genera (Pipiza and Triglyphus Loew, 1840) for the Oriental region and Downes et al. (2017) added the occurrence of the genus Trichopsomyia for this region comprising two species, based on one male from Kuala Lumpur, Malaysia, erroneously stated as originating from Indonesia, and a female from Vietnam. Another species, T. pilosa sp. nov. from Java is here described, based on males only.

The pilose katepisternum, well developed metasternum and the long pilose metafemur sets the Oriental and Australian specimens of the genus Trichopsomyia aside from all other known species in this group. The aim of this study is to give the first records and description of the Oriental species of the genus Trichopsomyia and to discuss the value of the character states of the pilosity of the katepisternum and the development of the metasternum in phylogenetic analyses.

\section{Material and methods}

The specimens were studied using a Leica Wild M10 stereo microscope with a 2.5 times drawing tube. Genitalia were soaked in barbers fluid and removed from the otherwise dry specimens by means of an 
entomological pin and afterwards briefly boiled in a $10 \% \mathrm{KOH}$ solution. The genitalia were stored in a genital vial containing glycerol after having been successively rinsed in $70 \%$ acetic acid, distilled water and $90 \%$ ethanol. The genitalia were drawn in liquid by use of the aforementioned drawing tube. Other figures were made by stacking several photos, using a Zerene Stacker 1.04, taken with a Canon EOS D6 camera equipped with a Canon MP-E 1-5 $\times$ macro lens and a Yongnuo YN14EX macro ring flash. The genitalia drawings and stacked images were further edited with the image editing program GIMP 2.8.14.

The terminology used is based on Thompson (1999), for the genitalia on Downes et al. (2017). All specimens used for Figs 3-5 are deposited in the private collection of the first author (JSA).

\title{
Repositories
}

The specimens studied are deposited in:

$\mathrm{NHM}=$ Natural History Museum, London, United Kingdom

JSA $=$ Private collection of the first author Jeroen van Steenis

\section{Results}

Class Insecta Linnaeus, 1758

Order Diptera Linnaeus, 1758

Family Syrphidae Latreille, 1802

Subfamily Pipizinae Williston, 1885

Genus Trichopsomyia Williston, 1888

\section{The Oriental species of Trichopsomyia}

\author{
Trichopsomyia pilosa sp. nov. \\ urn:1sid:zoobank.org:act:D4A23D4B-FCAC-4BEC-8B81-2583953DA34E
}

Figs 1-2, 3C

\section{Diagnosis}

Large, predominantly black and long black pilose pipizine; thorax black, extensively black pilose; wing brown infuscated; cell c wide; legs black with long pilose tarsi and metaleg; terga II and III with large rectangular brownish antero-lateral maculae; genitalia (Fig. 2) epandrium elongate; surstylus bilobed with rather long baso-dorsal process and with very long, elongate and slightly sickle-shaped narrow, elongate ventral process; hypoproct (see Downes et al. 2017) mushroom shaped, shaft on ventral surface densely but short pilose; hypandrium narrow, elongate with elongate rectangular process; postgonite (see Downes et al. 2017) dome-shaped in lateral view, with several small tooth in two rows on apicoventral surface.

\section{Etymology}

The specific epithet 'pilosa', the Latin word for 'hairy', refers to the extensively and long pilose katepisternum, the long pili on the metasternum and especially the long pilose metatibia. The name is to be treated as an adjective.

\section{Type material}

Holotype

INDONESIA - Java • đ̊; "Java: // Tjigaeha // i.1938 // coll. E. le Moult"; "QR-code // NHMUK 010864268"; NHM. 
Paratypes

INDONESIA - Java • 1 đ; same collection data as for holotype; "NHMUK 010864267"; JSA • 1 \%; "Java: // Gunung Malang // Djampang Wetan // ii.1938 // coll. E. le Moult"; "QR-code // NHMUK 010864266"; NHM.

\section{Description}

\section{Male}

LENGTH. Body 9.7-11.4 mm, wing 8.2-9.3 mm.

HEAD. Facial shape simple, in lateral view, almost straight, without central knob and without antennal tubercle; oral cavity round, smooth without notch; clypeus horse-shoe shaped; face black, black pilose; frons black, black pilose with two small white pollinose maculae laterally along eye margin (Fig. 1C); vertical triangle black, black pilose; eye pilose; postocular orbit dorsally broad; eye-contiguity relatively short, about a quarter as long as length of vertical triangle; antenna (Fig. 1D) orange-brown, elongate, basoflagellomere four times longer than broad.

Thorax. Black, extensively pilose; postpronotum pilose; katepisternum almost entirely pilose, only narrowly bare antero-dorsally and medially along posterior margin (Fig. 3C); katepimeron pilose; metasternum rather well developed with some pile medio-laterally.

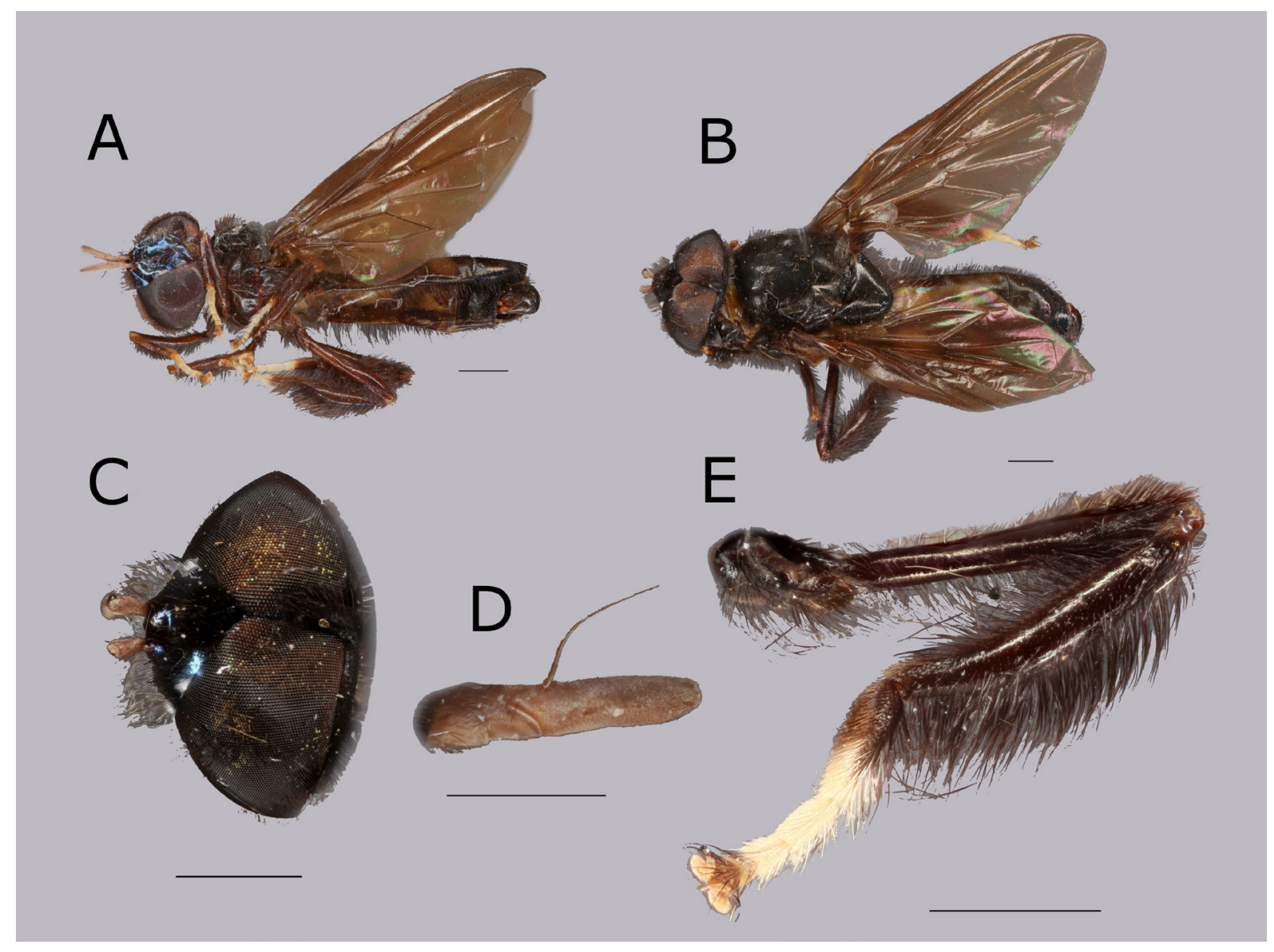

Fig. 1. Trichopsomyia pilosa sp. nov. A. Habitus, lateral view, holotype $\widehat{\partial}$ (NHMUK 010864268). B. Habitus, dorsal view, paratype $\widehat{\partial}$ (NHMUK 010864266). C. Head, dorsal view, paratype $\widehat{\partial}$ (NHMUK 010864266). D. Antenna, lateral view, holotype $\widehat{\jmath}$ (NHMUK 010864268). E. Metaleg, frontal view, paratype $\hat{\sigma}$ (JSA). Scale bars: A-C, E $=1.0 \mathrm{~mm}$; D $=0.5 \mathrm{~mm}$. 
WING. Membrane entirely brownish infuscated (Fig. 1A-B) covered with unusually long microtrichia, except bare on basal $1 / 10$ of cell bm; cell c exceptionally wide, clearly wider than cell bm; vein dm-cu ending almost perpendicularly to vein $M$; vein $M_{1}$ ending strongly oblique at vein $R_{4+5}$.

LEGS. Black, except apical half of basitarsi, and tarsomeres 2-4 white; pile long and predominantly black, but white parts of tarsi with long white pile; metaleg (Fig. 1E) with femur narrow and elongate, but slightly thickened and more densely long pilose apically; metatibia broad, laterally compressed and densely long-haired, hairs on dorsal surface longer than width of tibia.

ABDOMEN. Black and rather long black pilose; terga II and III each with one pair of large rectangular yellowish-brown maculae; pregenital terga black pilose.

Genitalia (Fig. 2). See under diagnosis and remarks.

\section{Female}

Unknown.
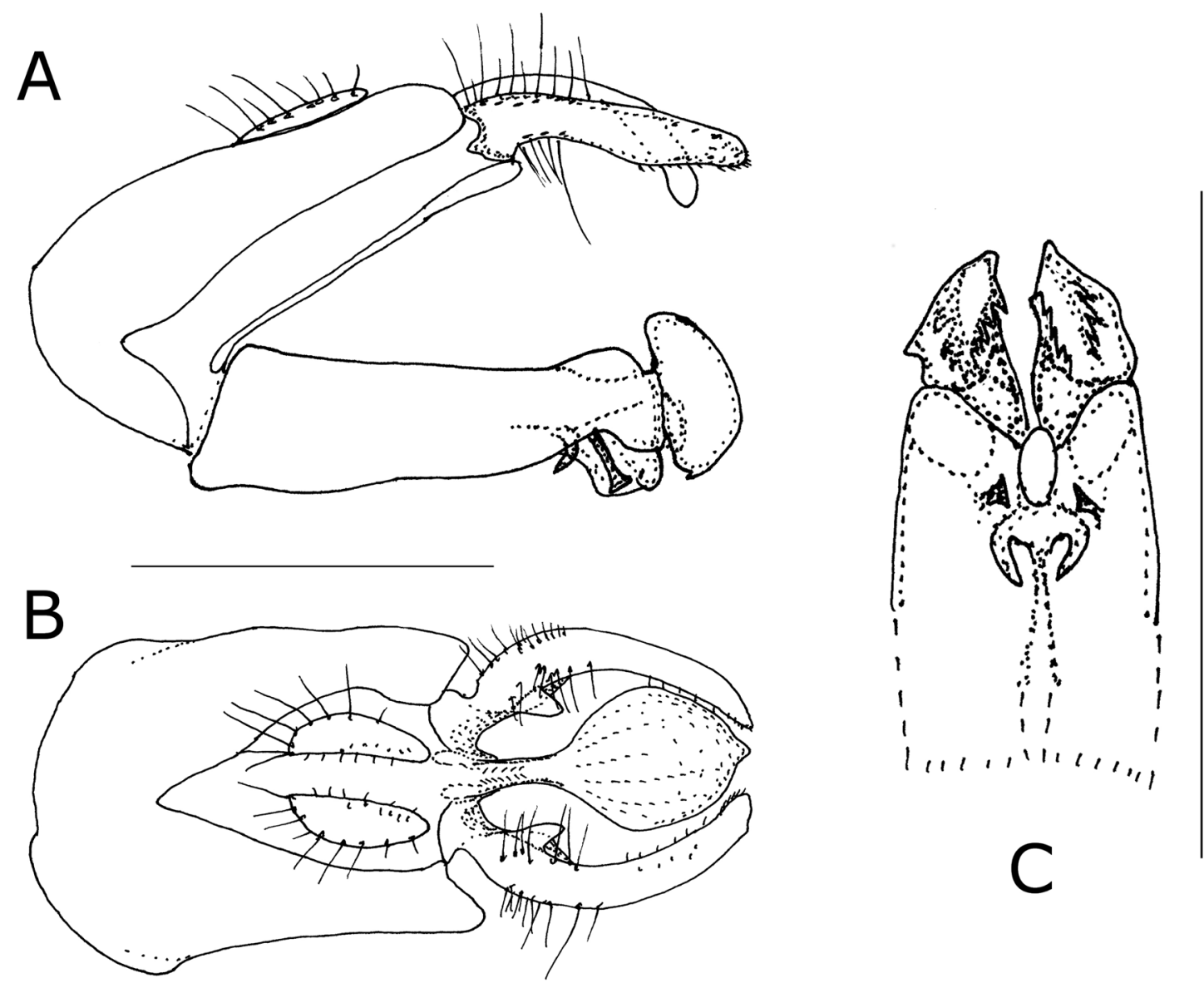

Fig. 2. Trichopsomyia pilosa sp. nov., male genitalia, holotype (NHMUK 010864268). A. Lateral view. B. Epandrium, dorsal view. C. Apical part of hypandrium, ventral view. Scale bars $=0.5 \mathrm{~mm}$. 


\section{Remarks}

According to the description and figures in Downes et al. (2017), our species is similar to the Australian Trichopsomyia formiciphila Downes, Skevington \& Thompson, 2017 based on the overall appearance of the species and especially the extent of pilosity on the katepisternum, the shape of the metasternum, the colour of the legs and abdomen, the long basoflagellomere and the infuscated wing with wide cell $\mathrm{c}$. Trichopsomyia pilosa sp. nov. differs from T. formiciphila by the long white pile on the tarsi, the very long black pile on the metatibia and several characters in the male genitalia like the surstylus with the apico-medial surface weakly and short pilose (more densely and long pilose in $T$. formiciphila); the shape of surstylus in ventral view weakly curved (more strongly curved in T. formiciphila); and the apico-dorsal gonocersus with weak teeth in two rows (stronger teeth present, not aligned in clear rows in T. formiciphila).

\section{Discussion}

\section{Phylogenetic characters for the Trichopsomyia formiciphila group}

All known genera of Pipizinae have clearly separated pile patches on the katepisternum (Mengual et al. 2015). In the character matrix of Hippa \& Ståhls (2005), Pipizella viduata (Linnaeus, 1758) and Trichopsomyia flavitarsis (Meigen, 1822) are, however, stated to be wholly pilose, but based on our observations this must be a type setting error. The two known species of Trichopsomyia from the Oriental and Australian regions are clearly differentiated from all other Pipizinae by the almost entirely pilose katepisternum, indicating these species are closely related and possibly form a subgroup within Trichopsomyia. The relatively bare katepisternum is also found in Microdontinae Rondani, 1845 (Reemer \& Ståhls 2013) and the following species: Brachyopa testacea (Fallén, 1817 ) (Fig. 5C) and B. obscura Thompson \& Torp, 1982 (Bot \& Van de Meutter 2019) while most other species of Brachyopa Meigen, 1822 have a ventral and a dorsal pile patch. In Myolepta Newman, 1838 and Eumerus Meigen, 1822, the extension of the pilosity differentiates between the M. dubia (Fabricius, 1805 ) and the E. tricolor (Fabricius, 1798) groups (medial pilosity, connecting dorsal and ventral pile patch), and the M. vara (Panzer, 1798) and the E. strigatus (Fallén, 1817) (sub)groups (only dorsal and ventral pile patch present) (Grković et al. 2019; Steenis 2020). On the other hand, an extensively pilose katepisternum is found in genera of different subfamilies like Scaeva Fabricius, 1805 (Fig. 3A) and Psilota Meigen, 1822 (Fig. 3B). The extent of pilosity differs widely within and between genera and even subfamilies, thus indicating this character is most likely highly homoplastic within Syrphidae and cannot solely be used to distinguish between genera.

The size and the shape of the metasternum is another widely used character in the phylogeny of Syrphidae (Thompson 1972; Hippa \& Ståhls 2005). Within the subfamily Pipizinae, the metasternum is poorly developed and the medial part is either round (in Pipiza) or slightly elongate (e.g., Pipizella Rondani, 1856 and Trichopsomyia) and always bare of pilosity. In the T. formiciphila group, the metasternum is rather well developed, and in T. pilosa sp. nov., it bears one pili on each side. The development of the metasternum is the key character used in differentiating between Melanostoma Schiner, 1860 on the one hand, and Platycheirus Lepeletier \& Serville, 1828 (Andersson 1970) and Afrostoma Skevington, Thompson \& Vockeroth, 2014 (Thompson \& Skevington 2014) on the other. The development of the metasternum as a key character in differentiating Afrostoma from Melanostoma was recently rejected by Mengual (2019) who synonymized these two genera. The extent and length of the pilosity were used to separate several genera of XylotinI Williston, 1886 (Hippa 1978), but also to separate Eupeodes (Lapposyrphus) lapponicus (Zetterstedt, 1838) from all other species of Eupeodes Osten Sacken, 1877 (Dušek \& Láska 1967). The use of the development of the metasternum and also its pilosity in separating species into different (sub)genera does not seem to be useful in all groups.

The male genitalia of the two species of the T. formiciphila group show some differences from other species of this genus, indicating a possible separate genus-group rank. 
Based on the extent of pilosity on the katepisternum, the size and the shape of the metasternum, and the differences in genitalia, the $T$. formiciphila group may deserve a sub-group ranking. Molecular data (Jeffrey Skevington pers. comm.), however, refute this and suggest that the T. formiciphila group is nested within Trichopsomyia. More genes and a quantitative morphological phylogeny should be explored to test these competing hypotheses, but until that is done, a new genus should not be erected for the T. formiciphila group. This, however, lies out of the scope of this paper and is left for future research preferably on the entire world fauna of Pipizinae including fossil forms as outlined in Nidergas et al. (2018).

\section{Pilosity on the katepisternum}

The pilosity of the katepisternum is widely used in phylogenetics of Syrphidae as a character to distinguish between genera (e.g., Vockeroth 1969; Hippa \& Ståhls 2005; Reemer \& Ståhls 2013; Mengual et al. 2015). The character states used by Hippa \& Ståhls (2005) for defining the extent of pilosity are: 0:

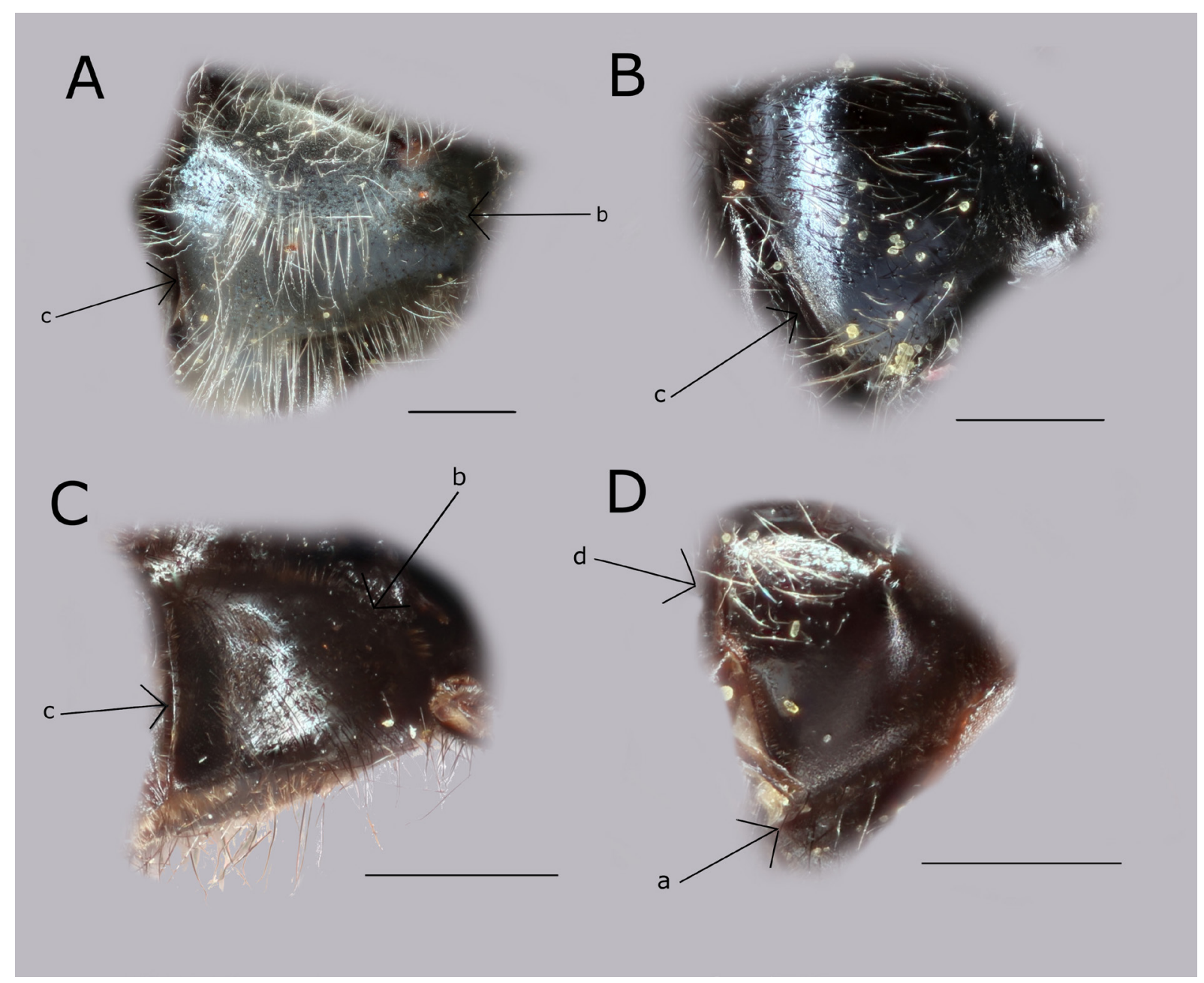

Fig. 3. Pilosity of the katepisternum, ventro-lateral view. A. Scaeva pyrastri (Linnaeus, 1758), 0 (JSA), Switzerland, with extensive pilosity. B. Psilota atra (Fallén, 1817), ô (JSA), the Netherlands, with extensive pilosity. C. Trichopsomyia pilosa sp. nov., paratype $\delta$ (JSA), with extensive pilosity. D. Trichopsomyia joratensis Goeldlin, 1997, + (JSA), Belgium, with separated dorsal and ventral pile patch. Scale bars $=0.5 \mathrm{~mm}$. $\mathrm{a}=$ ventral pile patch; $\mathrm{b}=$ antero-dorsal area; $\mathrm{c}=$ postero-medial margin; $\mathrm{d}=$ dorsal pile patch. 
entirely pilose, e.g., Callicera aenea (Fabricius, 1777), Ferdinandea cuprea (Scopoli, 1763) (Fig. 5A) and Temnostoma vespiformis (Linnaeus, 1758) (Fig. 4D); $1=$ dorsal and ventral pile patch present, e.g., Chrysogaster solstitialis (Fallén, 1817), Rhingia campestris Meigen, 1822, Spilomyia diophthalma (Linnaeus, 1758), Syrphus vitripennis (Meigen, 1822) and Xylota segnis (Linnaeus, 1758); $2=$ only dorsal pile patch present, e.g., Neoascia Williston, 1887 (Fig. 5B) and Sphegina Meigen, 1822. Character states 1 and 2 are rather clear, although in some genera the dorsal and the ventral pile patch are connected by a narrow row of pile medially, e.g., in Chrysogaster solstitialis and Syrphus vitripennis categorized in the new state 44A: 0 (see below). Entirely pilose, in many genera, is in reality only pilose on posterior $1 / 2$ to $3 / 4$ with medial part of posterior margin broadly non-pilose, e.g., Sphaerophoria scripta (Linnaeus, 1758), Volucella inanis (Linnaeus, 1758) and the under 'entirely pilose' listed species above. Besides Trichopsomyia pilosa sp. nov., we found only a few species with almost entirely pilose katepisternum, e.g., Mallota fuciformis (Fabricius, 1794), Psilota atra (Fallén, 1817) (Fig. 3B) and Scaeva pyrastri

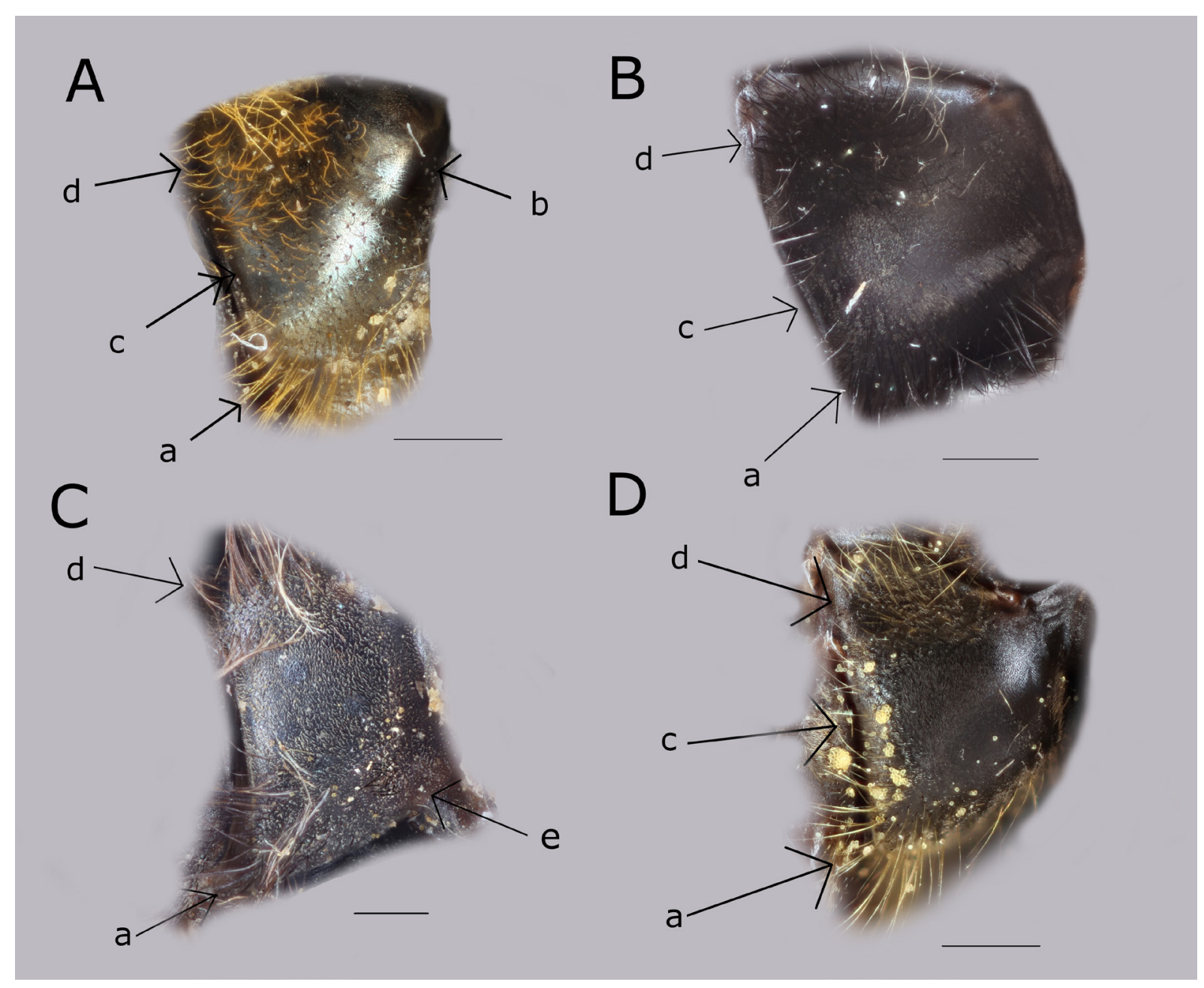

Fig. 4. Pilosity of the katepisternum, ventro-lateral view. A. Callicera macquarti Rondani, 1843, $q$ (JSA), Cyprus, with medially connected dorsal pile patch with entire pilose ventral margin. B. Eriozona syrphoides (Fallén, 1817), ô (JSA), Belgium, with posteriorly connected dorsal pile patch with entire pilose ventral margin. C. Pocota personata (Harris, 1780), o (JSA), Sweden, with three pile patches: dorsal, ventral and antero-medial. D. Temnostoma vespiformis (Linnaeus, 1758), ô (JSA), the Netherlands, with posteriorly connected dorsal and ventral pile patches. Scale bars $=0.5 \mathrm{~mm}$. a $=$ ventral pile patch; $\mathrm{b}=$ antero-dorsal area; $\mathrm{c}=$ postero-medial margin; $\mathrm{d}=$ dorsal pile patch; $\mathrm{e}=$ antero-medial pile patch. 
(Linnaeus, 1758) (Fig. 3A). On the other hand, in Pocota personata (Harris, 1780) (Fig. 4C) there are three pile patches, a postero-dorsal, a postero-ventral and an antero-medial one. There are also species where only a ventral pile patch is present, e.g., Brachyopa testacea (Fig. 5C). The entirely non-pilose condition is not known in Syrphidae (Hippa \& Ståhls 2005; Mengual et al. 2015). These examples make it clear that the old character states are much more complex and should be revised in the manner described below.

The three character states of the pilosity of the katepisternum are clearly not enough and should be extended to include all of the states as discussed above; however, for a phylogenetic analysis the number of codings is not unlimited. The proper use of the pilosity character has become more difficult and it is not easy to adjust this otherwise important character. The species in which the medial part of the katepisternum is pilose have always a ventral and dorsal pile patch, so the characters could be divided into two, numbered in accordance with Hippa \& Ståhls (2005): 44A: 0 = medial part of katepisternum pilose (Figs 3A-C, 4A-B, D, 5A); 1 = medial part of katepisternum bare (Figs 3D, 4C, 5B-D). The

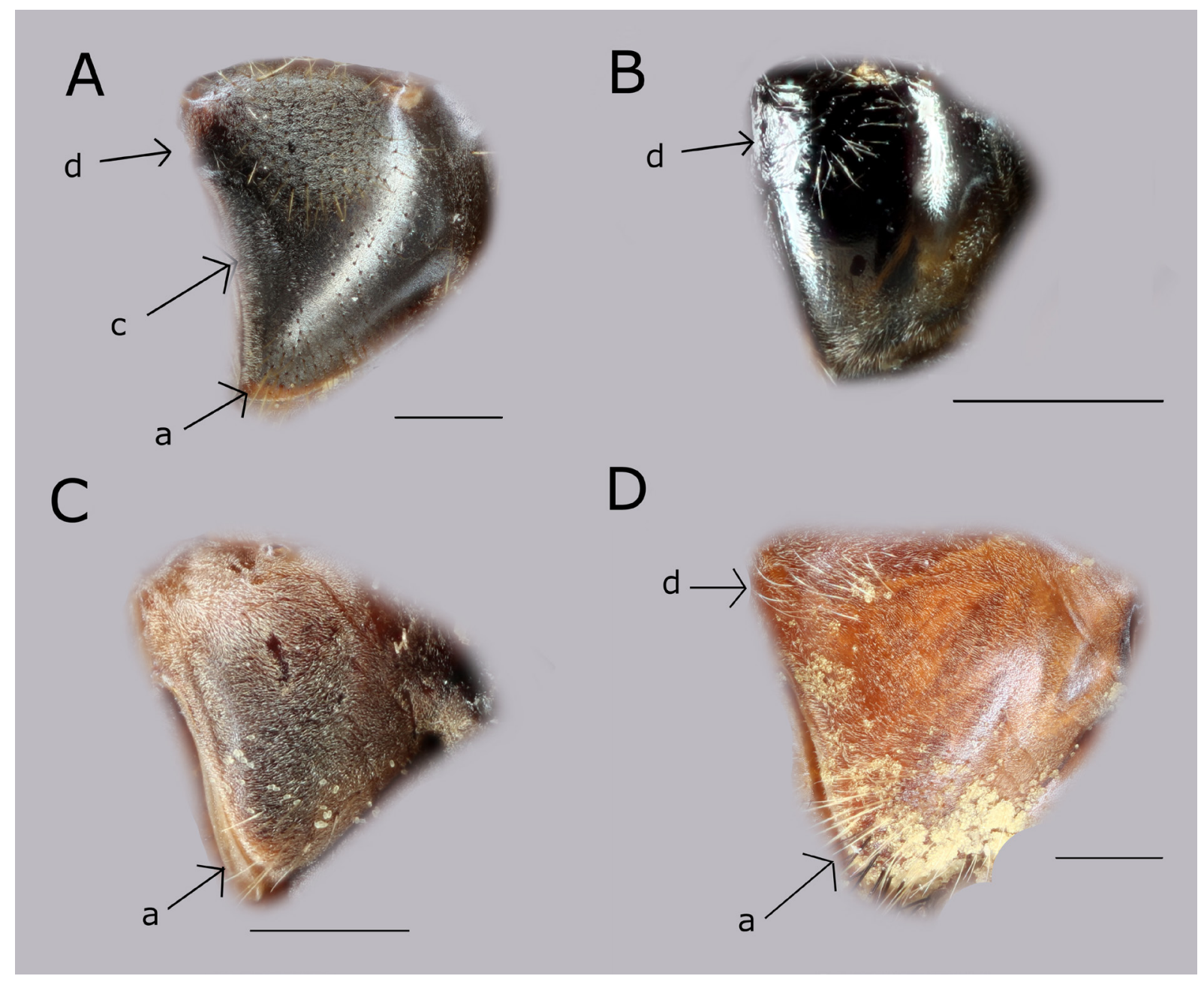

Fig. 5. Pilosity of the katepisternum, ventro-lateral view. A. Ferdinandea cuprea (Scopoli, 1763), $\widehat{0}$ (JSA), the Netherlands, with medially connected dorsal and ventral pile patches. B. Neoascia annexa (Müller, 1776), o (JSA), Germany, with ventral pile patch only. C. Brachyopa testacea (Fallén, 1817), $\widehat{\jmath}$ (JSA), Belgium, with dorsal pile patch only. D. Hammerschmidtia ferruginea (Fallén, 1817), đ̊ (JSA), Sweden, with dorsal and ventral pile patches, ventrally with additional long black setae. Scale bars $=0.5$ $\mathrm{mm} . \mathrm{a}=$ ventral pile patch; $\mathrm{c}=$ postero-medial margin; $\mathrm{d}=$ dorsal pile patch. 
first division differentiates between the former state 'entirely pilose' and is subdivided into four states: 44B0: $0=$ katepisternum extensively pilose, postero-medial margin at most narrowly bare and anterior $1 / 3$ and entire antero-ventral part pilose (Fig. 3A-C); $1=$ medial pile patch connecting dorsal and ventral pile patches, leaving at least the postero-medial area and the anterior half of the katepisternum bare (Figs 3C, 4, 5A); 2 = dorsal and ventral pile patches connected by narrow pilose area along posterior margin (Fig. 4B, D); 3 = three separated pile patches present (Fig. 4C). The second division (44A: 1) should then be subdivided into three character states: 44B1: $0=$ dorsal and ventral pile patches present (Figs 3D, 5D); $1=$ only a dorsal pile patch present (Fig. 5B); 2 = only a ventral pile patch present (Fig. 5C). In most species with character state 44B0: 2, the ventral pile patch is extended to cover almost the entire ventral margin of the katepisternum, while in the other species there is only a postero-ventral pile patch present.

\section{Acknowledgments}

Jeffrey Skevington (Ottawa, Canada), Ximo Mengual (Bonn, Germany) and Ante Vujić (Novi Sad, Serbia) gave valuable comments on the manuscript and discussed the possibility of erecting a new genus for the T. formiciphila group. The reviewers are acknowledged for their work in improving this manuscript. The visit by the first author to the NHM (London) was made possible by a funding through the Uyttenboogaard-Eliassen foundation under number SUB.2017.12.05.

\section{References}

Andersson H. 1970. Taxonomic notes on the genera Platycheirus and Melanostoma (Dipt., Syrphidae) with lectotype designations. Entomologica scandinavica 1: 236-240. https://doi.org/10.1163/187631270X00087

Bergh J.C. \& Short B.D. 2008. Ecological and life-history notes on syrphid predators of woolly apple aphid in Virginia, with emphasis on Heringia calcarata. BioControl 53: 773-786.

https://doi.org/10.1007/s10526-007-9114-0

Bot S. \& Van de Meutter F. 2019. Veldgids Zweefvliegen. KNNV Uitgeverij, Zeist.

Bugg R.L., Colfer R.G., Chaney W.E., Smith H.A. \& Cannon J. 2008. Flower Flies (Syrphidae) and Other Biological Control Agents for Aphids in Vegetable Crops. UC ANR, Publication 8285. Available from https://anrcatalog.ucanr.edu/pdf/8285.pdf [accessed 24 Jun. 2020]. https://doi.org/10.3733/ucanr.8285

Cheng X., Lu J., Huang C., Zhou H., Dai Z. \& Zhang G. 2000. Determination of phylogenetic position of Pipizini (Diptera: Syrphidae): based on molecular biological and morphological data. Science in China, series C 43 (2): 146-156. https://doi.org/10.1007/BF02879123

Downes M.F., Skevington J.H. \& Thompson F.C. 2017. A new ant inquiline flower fly (Diptera: Syrphidae: Pipizinae) from Australia. Australian Entomologist 44 (1): 29-38.

Dušek J. \& Láska P. 1967. Versuch zum Aufbau eines natürlichen Systems mitteleuropäischer Arten der Unterfamilie Syrphinae (Diptera). Acta Scientiarum naturalium Brno 1: 349-390.

Grković A., Smit J., Radenković S., Vujić A. \& Steenis J. van. 2019. Two new European long-legged hoverfly species of the Eumerus binominatus species subgroup (Diptera, Syrphidae). ZooKeys 858: 91-108. https://doi.org/10.3897/zookeys.858.34663

Hippa H. 1978. Classification of Xylotini (Diptera, Syrphidae). Acta Zoologica Fennica 156: 1-153.

Hippa H. \& Ståhls G. 2005. Morphological characters of adult Syrphidae: descriptions and phylogenetic utility. Acta Zoologica Fennica 215: 1-72. 
Hippa H., Steenis J. van \& Mutin V.A. 2015. The genus Sphegina Meigen (Diptera, Syrphidae) in a biodiversity hotspot: the thirty-six sympatric species in Kambaiti, Myanmar. Zootaxa 3954 (1): 1-67. https://doi.org/10.11646/zootaxa.3954.1.1

Huang C. \& Cheng X. 2012. Fauna Sinica. Insecta Vol. 50. Diptera, Syrphidae. Science Press, Beijing. Knutson L.V., Thompson F.C. \& Vockeroth J.R. 1975. Family Syrphidae. In: Delfinado M.D. \& Hardy D.E. (eds) A Catalog of the Diptera of the Oriental Region, 2, Suborder Brachycera Through Division Aschiza, Suborder Cyclorrhapha: 307-386. University Press of Hawaii, Honolulu.

Kuznetsov S.Y. 1988. Morphology of the eggs of hover flies (Diptera, Syrphidae). Entomologicheskoe Obozrenie 67 (4): 741-753. [In Russian.]

Kuznetsov S.Y. 1992. The first instar larvae of the subfamily Pipizinae and Eristalinae (Diptera, Syrphidae). Daba un muzejs, Riga 4: 24-43. [In Russian.]

Mengual X. 2019. Phylogenetic relationships of the bacchine flower flies (Diptera: Syrphidae) based on molecular characters, with a description of a new species of Melanostoma (Schiner, 1860). Contributions to Zoology 1410: 1-35. https://doi.org/10.1163/18759866-20191410

Mengual X., Ståhls G. \& Rojo S. 2015. Phylogenetic relationships and taxonomic ranking of pipizine flower flies (Diptera: Syrphidae) with implications for the evolution of aphidophagy. Cladistics 31: 491-508. https://doi.org/10.1111/cla.12105

Morales G.E. \& Wolff M. 2010. Insects associated with the composting process of solid urban waste separated at the source. Revista Brasileira de Entomologia 54 (4): 645-653.

https://doi.org/10.1590/S0085-56262010000400017

Mutin V.A. 1998. Cryptopipiza nom. n., new name for the genus Pseudopipiza Violovitsh (Diptera, Syrphidae). International Journal of Dipterological Research 9: 13.

Nidergas V., Hadrava J., Garrouste R., Prokop J., Schubnel T. \& Nel A. 2018. The first pipizine hoverfly genus and species from the Oligocene of Céreste, France. Acta Palaeontologica Polonica 63: 539-548. https://doi.org/10.4202/app.00500.2018

Pape T. \& Evenhuis N.L. (eds) 2019. Systema Dipterorum, ver. 2.2.

Available from http://sd.zoobank.org/Nomenclator [accessed 7 Jul. 2020].

Reemer M. \& Ståhls G. 2013. Phylogenetic relationships of Microdontinae (Diptera: Syrphidae) based on molecular and morphological characters. Systematic Entomology 38: 661-688.

https://doi.org/10.1111/syen.12020

Rojo S., Gilbert F.S., Marcos-García M.A., Nieto J.M. \& Mier Durante M.P. 2003. A World Review of Predatory Hoverflies (Diptera, Syrphidae: Syrphinae) and their Prey. CIBIO Ediciones, Alicante.

Rotheray G.E. \& Gilbert F.S. 1989. The phylogeny and systematics of European predacious Syrphidae (Diptera) based on larval and puparial stages. Zoological Journal of the Linnean Society 95: 29-70. https://doi.org/10.1111/j.1096-3642.1989.tb02222.x

Rotheray G.E. \& Gilbert F.S. 1999. Phylogeny of Palaearctic Syrphidae (Diptera): evidence from larval stages. Zoological Journal of the Linnean Society 127: 1-112.

https://doi.org/10.1111/j.1096-3642.1999.tb01305.x

Rotheray G.E. \& Gilbert F.S. 2011. The Natural History of Hoverflies. Forrest Text, Ceredigion.

Ssymank A. \& Kearns C. 2009. Flies-pollinators on two wings. In: Ssymank A., Hamm A. \& VischerLeopold M. (eds) Caring for Pollinators - Safeguarding Agro-Biodiversity and Wild Plant Diversity: 39-52. Bundesamt für Naturschutz, Bonn. 
Steenis J. van. 2020. A new species of the genus Myolepta Newman (Diptera: Syrphidae), with short description and key to all species of the M. vara subgroup. Zootaxa 4750 (3): 370-390.

https://doi.org/10.11646/zootaxa.4750.3.4

Steenis J. van \& Lucas J.A.W. 2011. Revision of the West-Palaearctic species of Pipizella Rondani, 1856 (Diptera, Syrphidae). Dipterist Digest 18: 127-180.

Steenis J. van, Gharali B., Zeegers Th. \& Sadeghi Namaghi H. 2018. Trichopsomyia ochrozona (Stackelberg, 1952) (Diptera: Syrphidae) recorded from Iran for the first time with a key to the West Palaearctic Trichopsomyia Williston, 1888 species. Zoology in the Middle East 64 (4): 345-359. https://doi.org/10.1080/09397140.2018.1511284

Thompson F.C. 1972. A contribution to the revision of the Neotropical Milesinae (Diptera: Syrphidae). Arquivos de Zoologia 23: 73-215.

Thompson F.C. 1999. A key to the genera of the flower flies (Diptera: Syrphidae) of the Neotropical region including redescriptions of new genera and species and a glossary of taxonomic terms. Contributions on Entomology, International 3: 319-379.

Thompson F.C. \& Skevington J.H. 2014. Afrotropical flower flies (Diptera: Syrphidae). A new genus and species from Kenya, with a review of the melanostomine group of genera. Zootaxa 3847 (1): 97 114. https://doi.org/10.11646/zootaxa.3847.1.5

Vockeroth J.R. 1969. A revision of the genera of the Syrphini (Diptera, Syrphidae). The Memoirs of the Entomological Society of Canada 62: 1-176. https://doi.org/10.4039/entm10162fv

Vujić A., Ståhls G., Ačanski J., Bartsch H., Bygebjerg R. \& Stefanović A. 2013. Systematics of Pipizini and taxonomy of European Pipiza Fallén: molecular and morphological evidence (Diptera, Syrphidae). Zoologica Scripta 42: 288-305. https://doi.org/10.1111/zsc.12005

Williston S.W. 1885. On classification of North American Diptera. Bulletin of the Brooklyn Entomological Society 7: 129-139.

Manuscript received: 17 December 2019

Manuscript accepted: 27 May 2020

Published on: 20 July 2020

Topic editor: Nesrine Akkari

Desk editor: Radka Rosenbaumová

Printed versions of all papers are also deposited in the libraries of the institutes that are members of the EJT consortium: Muséum national d'histoire naturelle, Paris, France; Meise Botanic Garden, Belgium; Royal Museum for Central Africa, Tervuren, Belgium; Royal Belgian Institute of Natural Sciences, Brussels, Belgium; Natural History Museum of Denmark, Copenhagen, Denmark; Naturalis Biodiversity Center, Leiden, the Netherlands; Museo Nacional de Ciencias Naturales-CSIC, Madrid, Spain; Real Jardín Botánico de Madrid CSIC, Spain; Zoological Research Museum Alexander Koenig, Bonn, Germany; National Museum, Prague, Czech Republic. 